\title{
HEALTH OF MIGRANTS AND MIGRANT HEALTH POLICY, THE NETHERLANDS AS AN EXAMPLE
}

\author{
H. P. UNIKEN VENEMA.' H. F. L. GARRETSEN' ${ }^{\prime}$ and P. J. VAN DER MAAS ${ }^{2}$ \\ 'Municipal Health Service of Rotterdam and surroundings. Department of Epidemiology, Schiedamsedijk \\ 95, 3000 LP Rotterdam. The Netherlands and 'Erasmus University, Department of Public Health, \\ Rotterdam. The Netherlands
}

\begin{abstract}
In The Netherlands, as in many other countries, many studies have addressed the health situation of migrant groups. After a discussion on methodological pitfalls in migrant studies, the articie reviews the most important results. The data show that there are differences in the health status and mortality patterns between migrant groups and the indigenous population. Most. but not all, of the differences are in disfavour of ethnic groups. Possible determinants of these differences are evident in socio/cultural, genetic and socio-economic factors. A model is presented that demonstrates the relation between these factors and health and disease.Implications for research and for health policy are discussed.
\end{abstract}

Key words-migrants, ethnic groups, morbidity, mortality

\section{INTRODUCTION}

Like most countries, The Netherlands harbour a large number of different ethnic groups (either defined by nationality and/or country of birth). There are several valid reasons for studying the health of these migrant groups.

One of these is that there are indications that when compared with the indigenous population migrants. and particularly those from so called "ethnic groups". are more susceptible to illness and suffer from a wider variety of ailments. They may, therefore, constitute a specific target for health policy.

Another reason is that insight into the disease patterns of migrating populations can contribute to understanding the aetiology of diseases. Studying how disease patterns of immigrants from various origins do, or do not, in time, assimilate to disease patterns of the indigenous population can promote the formulation of hypotheses on the role of environmental vs biological determinants of diseases. Migrant studies can also emphasize the universal validity of efforts to understand causes of disease. The high risk of ischaemic heart disease (IHD) among Asian immigrants in the United Kingdom, for example. can only be understood to a very limited degree through increased prevalence of known risk factors for IHD [1] This shows that what was believed to be general, universal knowledge on risk factors for IHD may be not so universal after all.

In The Netherlands most studies on the health of migrants are launched for policy reasons. In this article we will present a review of the available data. These data apply only to The Netherlands. Of a more general nature are the methodological problems that have to be dealt with in planning studies on migrant health and which may influence interpretation of the results. Also, the question of how to use these results in formulating health policy is one that crosses national boundaries.

In this article we will review the three following topics:

(1) Specific methodological issues regarding migrant studies.

(2) Differences in the health situation of migrants and the indigenous population of The Netherlands.

(3) Implications for health policy and research, emanating from the available data on the health status of migrants.

\section{MIGRANT GROUPS IN THE NETHERLANDS}

The largest migrant groups in The Netherlands are (in descending numerical order): Surinamese, Turks, Moroccans, Antilleans. Moluccans, Spaniards, Italians, Yugoslavians, Cape Verdeans and Portuguese. In 1991 over $6 \%$ of the population in Holland either has foreign nationality or originates from one of the former Dutch colonies. Of a total population of 15.000 .000 , there are 219,000 Surinamese, 198,000 Turks, 157,000 Moroccans and 71,000 Antilleans.

Surinamese and Antilleans migrated to The Netherlands mainly during the process of decolonization. Their motives for migration were various, and included greater opportunities for study, work, better social and health care facilities as offered in The Netherlands. family reunification, etc. Dutch is usually a first or second language. Most of the Surinamese, and all of the Antilleans have Dutch nationality.

Mediterranean groups came mainly as labour migrants, firstly men only (1960-1970), later to be 
followed by their families. Motives for migration were either work or family reunification. In their case, knowledge of the Dutch language is often limited or absent, especially among older women. Many Turkish and Moroccan women are illiterate, even in their own language. Very few Turks and Moroccans in The Netherlands are actually Dutch citizens.

Unemployment rates have reached $27 \%$ for Surinamese, $23 \%$ for Antilleans, $44 \%$ for Turks and $42 \%$ for Moroccans, compared to $13 \%$ for the indigenous population [2].

Most migrants in The Netherlands live in the larger cities, particularly in inner-city neighbourhoods. Turkish and Moroccan families live in smaller and inferior homes compared to the total population. For Surinamese and Antilleans housing conditions are better, but not yet equivalent to those for the Dutch.

\section{METHODOLOGICAL CONSIDERATIONS}

Before presenting data on morbidity and mortality of migrants in The Netherlands it is necessary to elaborate on problems that arise in almost any study regarding the health of migrant populations. A thorough understanding of these difficulties is a prerequisite to any interpretation of data.

\section{Measuring of 'ethnic background'}

It is virtually impossible, even theoretically, to formulate a perfect definition of a specific ethnic or migrant group. Ethnic groups are dynamic populations that can not be distinguished from a 'general" population by one specific trait. Most people that are considered to be "of ethnic origin', differ from the majority in either language, culture, skin colour. nationality, 'ethnic identity' (an individual's own sense of belonging) or ancestry, but none of these characteristics, or any combination thereof, constitute a widely accepted yardstick for ethnic origin.

In The Netherlands to date a person's nationality and/or country of birth, as well as those of his parents. are most frequently used to establish "ethnic background". In the case of Turks and Moroccans the determining factor is a combination of these two pieces of information. However, as Surinamese and Antilleans are mostly Dutch by nationality, the second detail is used as the chief indicator.

These methods of identifying ethnic groups are only temporarily viable, since the birthplace of parents will have no baring on the distinction between third generation migrants and the indigenous population. Also, in the future, nationality will be a less discriminating factor, as more foreigners acquire Dutch citizenship.

Once data from various sources are combined, a methodological problem arises as a result of the divers systems of regristration adopted to indicate ethnic background.

\section{Data-collection}

Standardized instruments are usually validated for use in the indigenous population only, and interpretation of the results for other groups remains hazardous. It seems likely that the more subjective the question, the more the answer is influenced by cultural bias. Therefore, transcultural comparisons when applied to some variables in health surveys can be questionable.

\section{Language}

Among Turks and Moroccans the level of proficiency in the Dutch language is low and the level of illiteracy high, so that oral interviews in the mother tongue are practically the only means of reaching a representative part of the population.

\section{Registration}

Whereas at least 120 sources of health statistics exist in The Netherlands, indications for ethnic background are seldom registered. Therefore such registrations as exist are useless as a basis from which to develop a research programme concerning the health of migrants.

\section{Reference groups}

Most studies are initiated in order to reveal whether migrants constitute a risk group with regard to health. The answer obviously depends on what one considers to be a relevant reference group. Data on migrant groups can either be compared to the total indigenous population, or to a reference group of, for instance, similar age, gender and/or socio-economic status, depending on the specific research question.

Some studies try to eliminate the effect of socio-economic status by accounting for this factor. This is so as to eliminate one potential determinant in order to be better able to study the effect of others, but also to answer the more practical question of whether migrants need special attention in a health policy that is already aimed at low socio-economic groups.

If one chooses to make comparisons within socio-economic groups, the fact that in some ethnic groups a considerable number of individuals have had no formal education whatsoever constitutes a major problem: no indigenous group can be found for comparison.

To develop insight into whether or not health problems of migrants are restricted to the current generation (cohort-effect), it would be interesting to compare data of the same age-groups within a particular ethnic group over a period of time.

Another relevant comparison can be made with the indigenous population of the countries of origin. Though it is difficult to obtain comparable data, such a comparison can shed a different light on the interpretation of health problems of migrants in the current country of residence. An example of this is given in the following paragraph on mortality. 


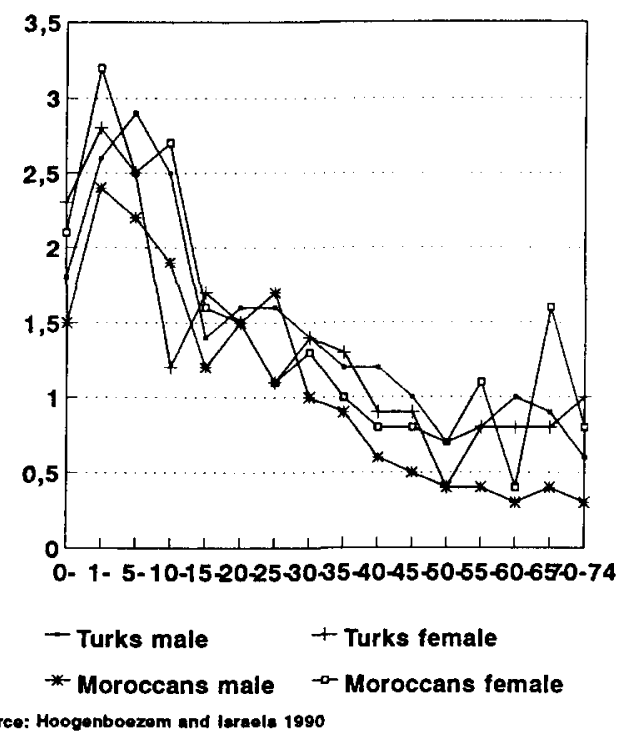

Fig. 1. Relative mortality rates of Turks and Moroccans compared to total population 1979-1988. Source: Ref. [3].

\section{MORTALITY}

Recent analysis by the Dutch Central Bureau for Statistics gives insight into relative mortality rates and causes of death for Turks and Moroccans [3]. For Surinamese and Antilleans only relative mortality rates (adjusted for age and gender) are available. They show that mortality is $20 \%$ higher for Surinamese and Antilleans than for the indigenous population [4]. No specific data relating to age or causes of death are available for these groups.

Mortality among Turkish and Moroccan children is much higher than for the indigenous population (Fig. 1). In the 1-5 years age-group, mortality is almost 2.5-3 times higher for Turkish and Moroccan boys and girls, compared to the total population of the same age*. With advancing age the differences in relative mortality rates diminish. In the older age-groups mortality rates seem to be somewhat lower for Turks and Moroccans. It has to be kept in mind however, that the absolute number of deaths is low, especially for Turkish and Moroccan adult women. Therefore conclusions on mortality rates among these groups can only be tentative.

The same caution is called for in interpreting data on causes of death [3]. Interpretation is further complicated by the fact that a substantial number of deaths of Turkish and Moroccan inhabitants of The Netherlands actually occur in their own countries, in which cases no causes of death were registered.

Turkish and Moroccan inhabitants die relatively often of infectious diseases and of external causes. Death from cancer is relatively low among these groups.

*Death in the first week after birth is excluded because of suspected underreporting for Turkish and Moroccan children.
Turkish children die more often than do Dutch children from infectious diseases, external causes (such as traffic accidents), congenital diseases and, in the case of Turkish girls, diseases of the respiratory system. The same causes occur relatively frequently for Moroccan children, although in their case, diseases of the respiratory system are more common with boys, and congenital diseases with girls.

Comparing discernable patterns relating to causes of death for Turks both in their homeland and in The Netherlands, and of indigenous Dutchmen show that those connected with the immigrants lie somewhere between those of the other two groups [5]. For example: For immigrant Turks cancer is a more prominent cause of death than for Turks in Turkey, but less so for Dutchmen. This can be regarded as an indication that the pattern of causes of death for Turks will in time come more into line with that of the indigenous population in The Netherlands. Also, international studies have shown that such patterns within migrating populations shift slowly towards that of the indigenous population [6].

\section{MORBIDITY}

Out of all the migrant groups, only in the case of Turks is extensive information on health available from several surveys [7-10]. As the survey based on interviews carried out by the Central Bureau for Statistics (CBS) covers by far the largest sample this is the main source of information for this article.

In 1989 and 1990 the CBS conducted a national health interview survey among a random sample of Turkish households in The Netherlands. In 1373 households information was gathered on 5306 individuals. Interviews were conducted in Turkish, male interviewers interviewed male respondents, females interviewed female respondents. For children (under 16) proxy-interviews were held with parents. The CBS also regularly conducts health interview surveys among the indigenous population. Dutch respondents interviewed in this conext in 1989 and 1990 served as a comparison group.

This study shows that, contrary to the mortality figures, up to approx. 24 years of age there is little difference between the state of health as reported by Turkish and Dutch youngsters. Adult Turks give less positive answers to almost all questions regarding their own health, when compared to Dutch adults (Table 1). The percentage of respondents reporting ill health increases with age for Turks and Dutch adults alike. For Turkish respondents this deterioration is reported as starting at a younger age and proceeding more rapidly (Fig. 2). Figure 3 shows that both for Turks and for the Dutch, considerable socio-economic health differences exist, but for every single educational level the Dutch regard their health status better than do the Turks.

Most chronic disorders have a higher prevalence 
Table 1. Results of national health survey, Turkish and Dutch respondents (16 years and over), adjusted for age

\begin{tabular}{lccccc}
\hline & \multicolumn{2}{c}{ Turks (3389) } & & \multicolumn{2}{c}{ Dutch (15860) } \\
\cline { 2 - 3 } \cline { 5 - 6 } \cline { 5 - 6 } & Male & Female & & Male & Female \\
\hline Self reported health 'so so'/poor & $25.1 \%$ & $27.7 \%$ & & $10.3 \%$ & $12.1 \%$ \\
Average number of chronic diseases & 0.6 & 0.6 & & 0.3 & 0.4 \\
Persons with one or more chronic diseases & $34.6 \%$ & $32.1 \%$ & & $22.6 \%$ & $27.4 \%$ \\
Number of health complaints & 5.5 & 7.7 & & 2.5 & 3.6 \\
$\quad(m a x .=23$, high $=$ bad health) & & & & \\
\hline
\end{tabular}

Source: CBS 1991

among Turks, particularly stomach ulcers and low back pain.

Although no large scale health surveys have been held among other ethnic groups, there are indications from smaller studies that for Moroccans and Surinamese, subjective health is likewise worse than for the indigenous population [11-16].

Due to the methodological problems discussed before it is, however, difficult to accurately interpret the results of differences in self-reported health. The validity of comparing these data between groups with a different cultural background can be questioned. This is especially true regarding the questionnaire on subjective health and the general evaluation of the individual health status. This leads to the question: Are we measuring the same factors in both groups?

It is therefore important to also look at data collected in health care institutions. Earlier studies of this kind show that infectious diseases are more frequent among Turks and Moroccans [17-19]. A study based on medical diagnoses showed that Turkish and Moroccan men seem to suffer more frequently from stomach ulcers [20]. This is clearly consistent with the data gathered in the health survey among Turks. Also Turkish and Moroccan men are more frequently registered at clinics for sexually

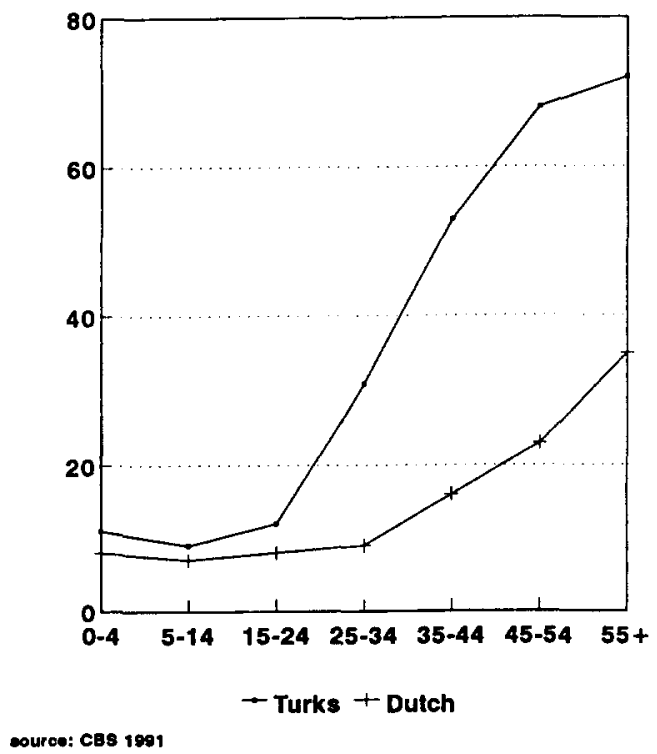

Fig. 2. Percentage of respondents reporting own health as 'so so'/bad per age group. Source: Ref. [7]. transmitted diseases than expected from the total population figures [21].

From a study among general practitioners it is known that Turkish as well as Moroccan adults consult their general practitioner more often for digestive problems than do Dutch and Surinamese adults [22]. For children of all four groups respiratory and skin diseases are the most common reasons for visiting the doctor, the former being the most prevalent particularly with Turkish and Moroccan children of both sexes and with Surinamese boys.

15 year old Surinamese and Moroccan children rate their own health significantly less often as 'good' than do Dutch children of the same age, gender and and educational background [9]. No differences exist in the total average of (reported) chronic diseases though there are differences in prevalence with some diseases. Turkish and Surinamese children report more psychosomatic complaints.

\section{MENTAL HEALTH}

It is likely that migrants are more exposed to potential stress factors than are Dutch people, and will accordingly suffer more mental health problems. Unfortunately, representative data on the prevalence of psychosocial or psychiatric problems are not available.

Data from psychiatric hospitals show higher admission rates for Surinamese and Antillean men and women and for Moroccan men, and lower admission rates for Turks of both sexes and for Moroccan

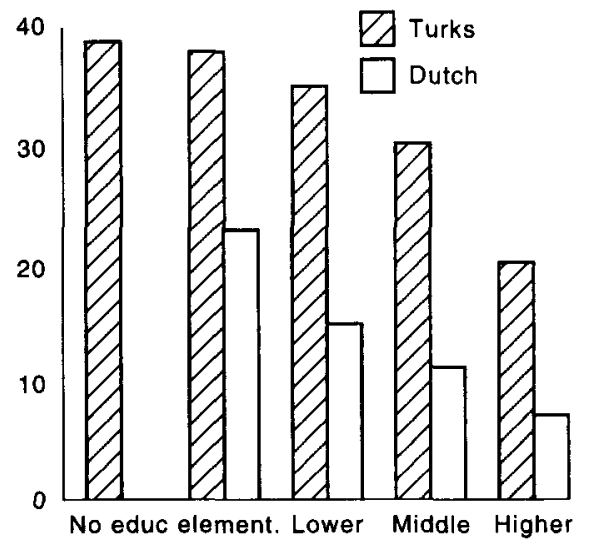

Fig. 3. Percentage of respondents reporting own health as 'so so'/bad per educational level. Source: Ref. [7]. 


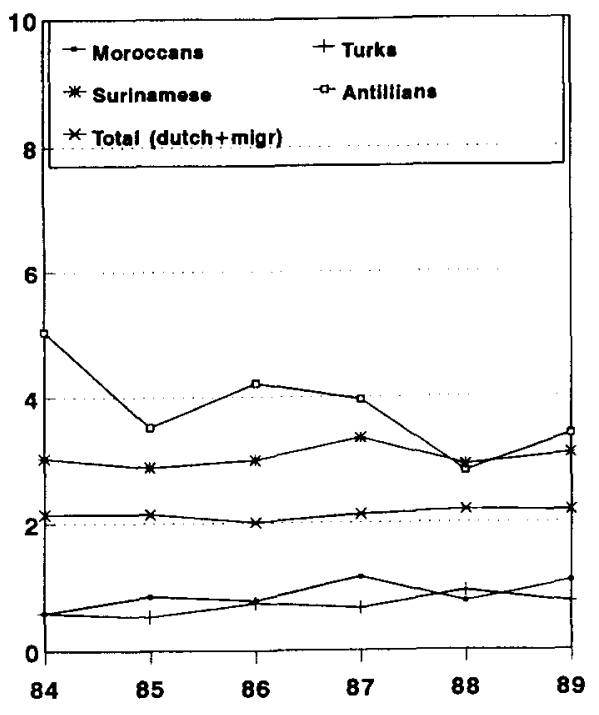

Source: Unlken Veneme and Wlordema 1902

Fig. 4. Admissions of women to psychiatric hospitals 1984-1989 (per 1000 of the population). Source: Ref. [23].

women, when compared to those of the total population in The Netherlands [23] (Figs 4 and 5).

A problem in the interpretation of these data is that hospital administrations and population statistics do not use the same criteria for identifying ethnic groups. In this case, however, the variation in admission rates between groups was of such magnitude that it is highly unlikely that this factor can be responsible.

It is uncertain whether these variations in rates of admission can be attributed to a varying prevalence of psychiatric problems or to factors regarding the accessibility of psychiatric care, to cultural factors, etc.

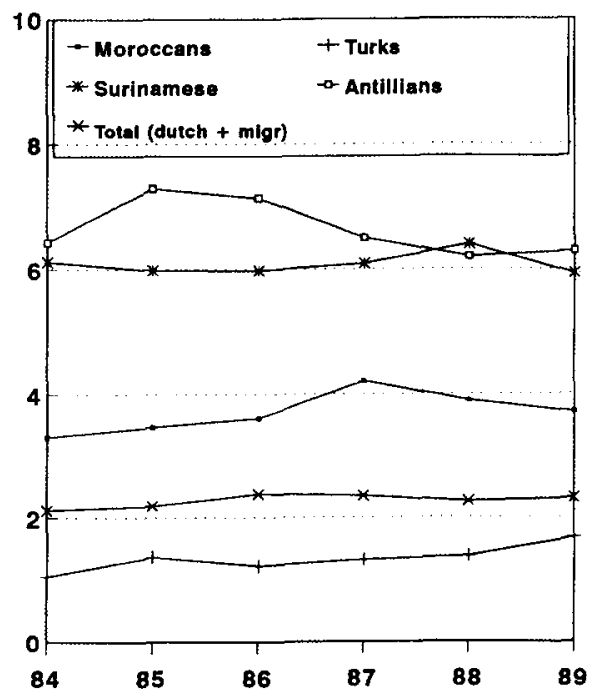

Source: Uniken Venema and Wlerdarme 1992

Fig. 5. Admissions of men to psychiatric hospitals 1984-1989 (per 1000 of the population). Source: Ref. [23].
Table 2. Summary of data on health and ethnicity in The Netherlands

\begin{tabular}{|c|c|c|c|}
\hline & Turks & Moroccans & $\begin{array}{c}\text { Surinamese/ } \\
\text { Antilleans }\end{array}$ \\
\hline Child morlality & - & - & $\mathrm{x}$ \\
\hline Adult mortality & 0 & 0 & $\mathbf{x}$ \\
\hline Totil mortality & & & - \\
\hline \multicolumn{4}{|l|}{ Mortaliug fiom: } \\
\hline Infectious diseases & - & - & $\mathbf{x}$ \\
\hline Exlernal caluses & - & - & $\mathrm{x}$ \\
\hline Cancer & + & + & $\mathrm{x}$ \\
\hline Self-reported health (general) & - & - & - \\
\hline Reported chronic diseases & - & $\mathbf{x}$ & $\mathbf{x}$ \\
\hline Stomich ulcer & - & $\mathrm{x}$ & $\mathrm{x}$ \\
\hline $\begin{array}{l}\text { Admissions to } \\
\text { psychiatric hospitals }\end{array}$ & + & $\begin{array}{c}- \text { (men) } \\
+ \text { (women) }\end{array}$ & - \\
\hline \multicolumn{4}{|c|}{$\begin{array}{l}+ \text { Belter health or less mortality or fewer hospital admissions } \\
\text { (compared to total population). } \\
- \text {. Inferior health or more mortality or more hospital admissions } \\
\text { (compared to total population). }\end{array}$} \\
\hline x. No or not sufficient empiri & & & \\
\hline
\end{tabular}

\section{DISCUSSION}

Despite the methodological problems mentioned earlier, the data shown lead to the conclusion that there are differences in health status and mortality patterns between migrant groups and indigenous populations. Table 2 presents a summary of the results.

As was mentioned in the Introduction, most studies on the subject in The Netherlands are initiated to supply information to contribute towards health policy. Therefore it is important to understand the factors contributing to health differences between the various groups.

\section{Determinants}

Ethnic background can be related to health problems in many complex ways, as will be discussed below. There is, however, also the question of a health-related policy connected with the initial selection of migrants that needs to be taken into account. In the first generation of Turkish and Moroccan immigrants, the labour migrants, healthy men were certainly primarily targeted by Dutch companies. This does not explain the health problems as reported by the older Turks, but it may be that the lower mortality figures have something to do with this initial bias towards physically fit men.

Three factors can be identifed that may explain how ethnic background relates to health: biological/genetic factors, socio-economic factors and socio-/cultural factors. Figure 6 presents a simplified model of the ways these factors relate to health. The relationships indicated in the model are not an exhaustive enumeration of all possible relations. Rather, the model represents the most likely mechanisms based on present knowledge of migrants in The Netherlands. For easy reference, the selective (re)migration is ignored in this figure.

Basically the three main factors (second column in Fig. 6) affect the health status of individuals through 
intermediary factors (third column in Fig. 6). These intermediary factors relate to factors that directly determine incidence and prognosis of diseases (fourth column in Fig. 6). We will discuss the three main clusters and the five determining factors.

\section{Biologic/genetic factors}

Biologic/genetic factors can be related to health and disease both directly and indirectly. In English and American literature many authors argue that the concept of 'race' should be replaced by the concept of 'ethnicity' because 'race' refers too much to genetic differences whereas the main cause for differences in health between ethnic groups is believed to be social rather than genetic [24]. Yet there is evidence that genetic variations can be relevant in explaining health differences between ethnic groups $[25,26]$. For example, genetic factors were proved to account for differing levels of susceptibility to non-insulin-dependent diabetes and hypertension between blacks and whites in the United States [25]. The prevalence of Thalassaemia among Mediterranean immigrants is a Dutch example of a disease resulting from genetic differences.
In The Netherlands as yet no studies have been carried out that have established the role of genetic factors in explaining health differences between ethnic groups.

The indirect influence that biologic factors can have on health status is through discrimination. Discrimination can be evoked by physical characteristics of the subjects. Experiences of discrimination can put an extra strain on both the materialistic living conditions (access to labour, housing) and the psychosocial well-being of migrants.

\section{Socio-cultural factors}

Migrants in The Netherlands originate from cultural backgrounds that differ from those of the indigenous population. Since culture involves many health-related notions (e.g. nutrition, life-style, ideas on adequate treatment of illness, etc), cultural differences can be important in explaining those of health. Despite this general notion, it is important to stress that cultures of the various migrant (sub-)groups and individuals as well as 'the' culture of the different indigenous sub-groups, change permanently as a result of changing circumstances.

\begin{tabular}{|c|c|c|c|c|}
\hline Determinant & Main factors & $\begin{array}{l}\text { Intermediary } \\
\text { variables }\end{array}$ & $\begin{array}{l}\text { Factors determining } \\
\text { incidence and } \\
\text { prognosis of diseases }\end{array}$ & Outcome \\
\hline
\end{tabular}

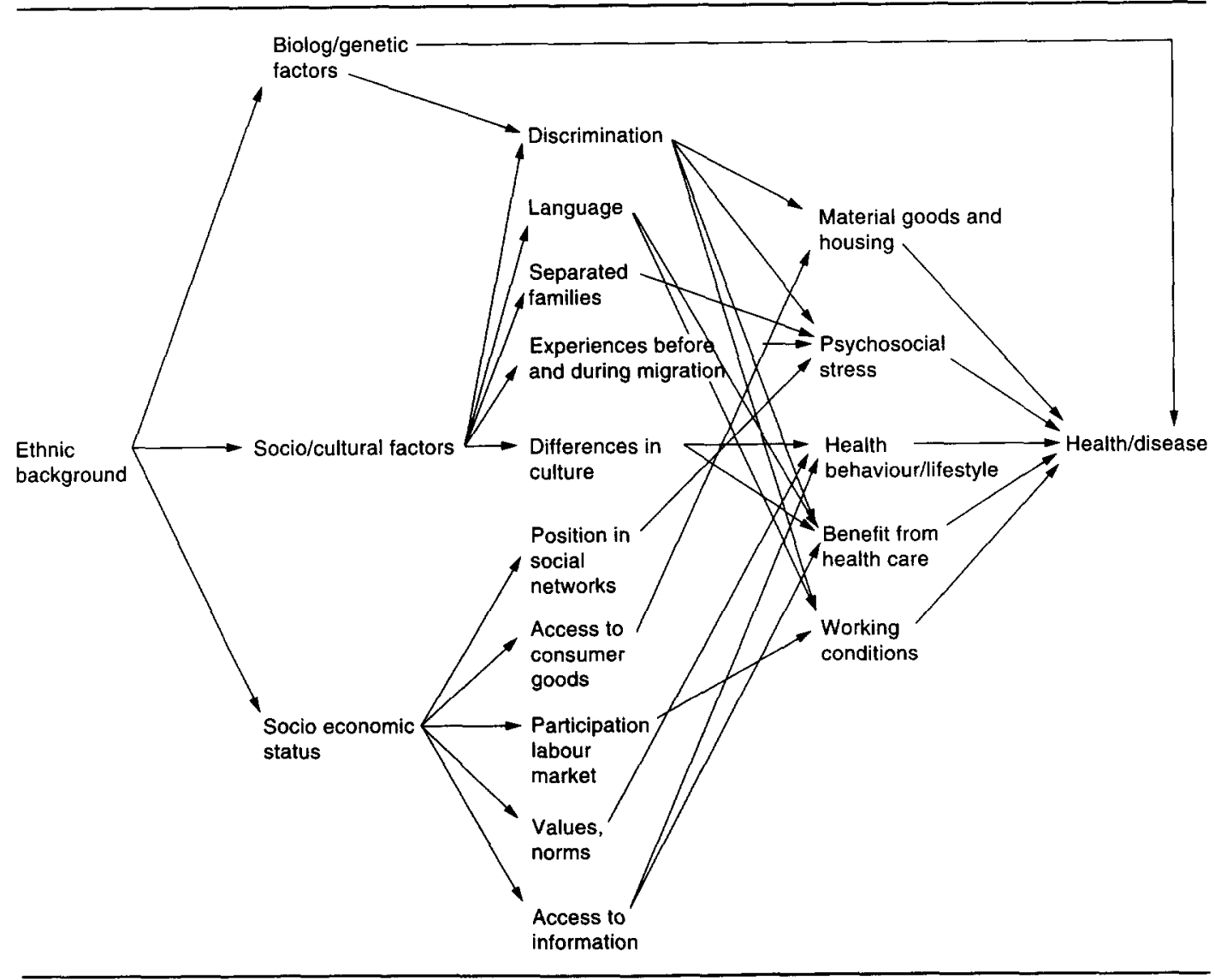

Fig. 6. Explanatory model of the relationship between ethnicity and health. 
A considerable number of the Turks and Moroccans in The Netherlands cannot, or are less capable, of speaking Dutch. This is, of course, not a direct threat to health, but it can hamper effective communication with doctors. Language problems also inhibit access to information on health and health care.

The standard of health amongst natives is largely determined by the quality of health care in that country. Migrants in The Netherlands who grew up in Turkey or in Morocco, particularly in rural areas. consequently may suffer from ailments as a result of neglected health problems dating from their youth.

For many, migration itself is a potentially stressful event. In the case of all four groups mentioned in this article, migration has split up families temporarily or permanently. In a qualitative study among Turkish women many of them indicated that living apart from their parents is a constant source of grief and worry [10].

Many authors emphasize the effect that cultural chnge has on mental health (a.o. [27, 28]). This "culture shock' is supposed to be more pronounced where differences between the old and new culture are greater. This cultural gap is probably most pronounced in the case of Turkish and Moroccan immigrants from small rural villages. Qualitative studies among Turkish families in The Netherlands, however, have often showed that the transition has been more gradual and less traumatic than the culture shock theory' would indicate.

\section{Socio-economic status}

As mentioned before, Turks and Moroccans and, to a lesser degree Surinamese, are found mainly in lower socio-economic groups. Therefore, many of the factors that explain health problems within these groups may also partly account for those of migrants. The complexity of the relationship between socioeconomic status and health is discussed in full elsewhere [29]. For our purpose we use a simple model of 'intermediary factors' (Fig. 6). Some of these factors (availability of consumer-goods, limited access to the labour market because of low educational level) are probably even more relevant for explaining health problems of migrants.

\section{Factors determining incidence and prognosis of diseases}

(a) Material goods and housing conditions. To an even greater extent than natives of lower socio-economic status groups, Turks and Moroccans in The Netherlands live in overcrowded houses that are sometimes in very poor conditions, usually concentrated in inner-city neighbourhoods. It can be expected that this is relevant for both the higher mortality of infectious diseases and for the higher incidence of accidents among these groups.

(b) Working conditions. The first Turkish and Moroccan migrants in The Netherlands were hired to take the jobs the indigenous population was no longer was prepared to do. Even now, migrants are often employed in physically heavy jobs. Maybe this phenomenon can partly explain why the health amongst Turks deteriorates at a much younger age, when compared to the Dutch population.

(c) Lifestrle. To their advantage migrant groups particularly Turks and Moroccans, adopt a healthier lifestyle regarding nutrition than do the indigenous population $[30,31]$. These two groups appear to have lower levels of serumcholesterol [30,32, 33]. Also alcohol consumption seems to be far lower than it is among the indigenous population.

Obesity, on the other hand, is measured more often in Turkish than in Dutch groups $[7,32,33]$. The prevalence of smoking is higher among Turkish men, but not among Turkish women [33-35].

(d) Adequate use of health care. The health care system in The Netherlands contains few financial barriers. In both quantitative and qualitative studies it was shown that the accessibility of curative health care for Turks, Moroccans and Surinamese was high $[7,16,18,36]$. It is very likely, however, that due to cultural and communication barriers migrants benefit less from health services than do most indigenous patients [37-39]. Differences in culture and language between patient and doctor can lead to stereotyped ideas among doctors concerning ethnic patients, disregarding both the fact that migrants differ individually and that 'culture" is not static, but always subject to change.

Also the fact that Turks and Moroccans tend to respond less well to preventive health activities such as dental care and screening for cancer of the cervix may contribute to unfavourable health differences [7, 40].

(e) Psychosocial stress. As was mentioned in a previous paragraph, no data are available on the prevalence of psychosocial stress among migrants in The Netherlands. As is shown in Fig. 6 there are more possible 'sources' of stress for migrants than for the indigenous population.

Although extensive literature exists on the theoretical contribution of these variables, only rarely is an attempt made to statistically investigate the intermediary factors contributing to health differences between various ethnic groups.

This lack of empirical data is not so surprising when one realizes that it is hard to design a study that can provide "proof" regarding the effect of many of these factors. It is difficult to design an observational study because too many determinants change simultaneously, and many of the determinants apply to most of the migrants. This means that there would not be sufficient variance in the exposed group to unravel the processes involved.

Despite these difficulties, we believe that with a theoretical model of possible determinants, such as we have attempted to develop in this article, it will be possible to develop studies that will contribute to a better understanding of the relevance of specific determinants for specific diseases. 


\section{Implications for research}

Future research should follow two major paths: a descriptive and an explanatory one. Whereas the first should be aimed at filling in gaps which give information on the health of Moroccans, Surinamese, Antilleans and other migrant groups, the second should help gain insight into determinants of specific health problems.

The descriptive approach would, of course, greatly benefit from special research projects.

Ideally, however, indicators for both ethnic background and socio-economic status would be included in national and local health registers. Findings in these registers could, without any great additional cost, reveal those areas requiring special attention in research or health policy when applied to specific groups. This applies particularly to records from hospitals that are already gathered and analysed on a national level, and could provide relevant information. Registration of such sensitive indicators should of course only be effected if adequate measures taken on concerning protection of privacy. Dutch law, which imposes rather strict measures on privacy for all forms of records, seems to cover this.

Other criteria that can be used to establish priorities in research are: the preponderance of a group in society, quantitative and qualitative information on the existence of health risk factors (such as, again, socio-economic status) and qualitative information from health workers or other sources.

The second approach in research should entail gaining insight into the background of major health problems of migrants. Future studies need to be more specific, aimed at well defined health problems or diseases. For every phenomenon under study a theoretical 'model of determinants' needs to be designed and a relevant course of study adopted. Thus, a number of issues need to be addressed: The mortality of Turkish and Moroccan children from infectious and congenital diseases and external causes. The patterns of admission to psychiatric hospitals of different migrant groups demand further clarification. Both the prevalence of psychiatric and psychosocial problems and the extent to which individuals with these problems avail themselves of medical, including psychiatric services, need to be studied for each of the different ethnic groups.

More difficult to address in future research is the general poor health as reported by Turks (and. probably, by other migrants). It is very likely that all of the possible determinants mentioned before. and possibly many more, are relevant to some degree, and that the combined influence of many of these factors determines general health perception. Once again, it will be very difficult to design a course of study that 'isolates' some specific determinants.

In both approaches it is important to bear in mind that ethnic groups are far from homogenous. As in the majority population there are enormous differences within ethnic groups with regard to many health-related aspects, e.g. socioeconomic status, culture, language skills etc. Future studies on ethnicity and health should therefore preferably not only contain indicators for ethnic background, but also on socioeconomic and cultural variables.

\section{Implications for health policy.}

Most available data on the health of migrants are rather general in nature. They show that Turks are at higher risk as regards most health problems than are Dutchmen, regardless of age, gender or socio-economic status. General data can only lead to general policy recommendations: The fact that Turks constitute a particular risk group within the lower socio-economic status groups indicates that attempts to ensure that ethnic groups benefit equally from health promotion or intervention campaigns are insufficient. Additional efforts and funds must be invested in preventive measures for this group within action programs aimed at underprivileged groups.

This notion is generally applied in many of the 'healthy cities' initiatives that are carried out in large cities in The Netherlands. Migrants are an explicit target group in many of these programmes. A good example is the 'migrant and health' project run in a Rotterdam neighbourhood. Project workers provide health education programmes for migrants, run consulting hours for them and motivate them into taking a more active stance in promoting their own health. They encourage cooperation between health care workers and motivate non-health related institutions in the neighbourhood (such as housing corporations and schools) to work together in improving general living conditions.

There are a few data that are more specific and can be more directly related to policy-measures. The high mortality rates among Turkish and Dutch children are partly due to causes that have to a certain extent to do with parental care (infectious diseases and external causes). In health education and promotion programmes for migrant women, prevention of infectious diseases and of accidents have become important topics. Also other steps are taken towards improving childrens" safety in impoverished areas in inner cities, where most migrant children live.

Although the specific importance of all the different determinants of diseases in contributing to the ill-health of Turks is unknown, it is possible to develop preventive initiatives aimed at this group for some of the diseases for which they form a high risk group. Infectious diseases are a good example. Since the methods of transmission for most infectious diseases in a community are known, it is possible to design health education programmes accordingly.

\section{CONCLUISION}

Available data support the notion that (at least some) ethnic groups deserve special attention in health 
policy. Though they probably share a lot of health risks with Dutch people of similar low socio-economic status, there are strong indications that the effect of all combined risk factors is more detrimental to them. The standard of health as reported by individuals in this group is less favourable than that of Dutchmen, mortality is high for Turkish and Moroccan children and some infectious diseases seem more prevalent among Turks and Moroccans. Little data exist on mental health of migrant populations in The Netherlands.

Methodological considerations that must be taken into account when comparing data on the health of different ethnic groups concern the measurement of ethnic background, data-collection and the choice of adequate reference groups. Some of these problems cannot be completely resolved. Nevertheless most data from different sources point in the same direction.

In general, the data lead to the conclusion that extra attention is required, concerning the health of migrants. Also in the case of action programmes such as that of the WHO healthy cities, which are already aimed at low socio-economic status groups, specific efforts must be made to improve the standard of health amongst migrants. More specific aims at childrens' safety and the prevention of infectious diseases must be important topics in health education programmes.

\section{REFERENCES}

1. Knight T., Smith Z., Lockton J. A., Sahota P., Bedford A., Toop M., Kernohan E. and Baker M. R. Ethnic differences in risk markers for heart disease in Bradford and implications for preventive stategies. $J$. Epidemiol. Commun. Hith 47. 89, 1993.

2. WRR. Allochtonenbeleid. SDU, 's Gravenhage. 1989

3. Hoogenboezem J. and Israëls A. Z. Sterfte naar doodsoorzaak onder Turkse en Marokkaanse ingezetenen in Nederland, 1979-1988. Maandbericht gezondlheid (CBS) 8, 4, 1990.

4. Tas R. F. J. Surinaamse en Antilliaanse bevolking in Nederland, 1 januari 1991. Maandstatistick toor de bevolking (CBS) 1, 6, 1992.

5. Mackenbach J. P. Ziekte en sterfte onder Turken in Nederland. Nederlands Tijdschrift voor Geneeskimde 136. 1044, 1992.

6. Kliewer E. Epidemiology of diseases among migrants. Brussel: Paper presented at the Intemational Organi:ation on Migration and Health, 1992.

7. De gezondheidsenquete Turkse ingezetenen in Nederkand 1989/1990. CBS, Voorburg/Heerlen, 1991.

8. Danz M. J., Gründemann R. W. M. and Koopman D. Klasgenoten. De Situatie ran Turkse en Nederlandse' Jongeren Vergeleken. NIPG/TNO. Leiden. 1987.

9. Stolwijk A. M. and Raat H. Gezondheid en Leefwijzen rum Surinaamse, Turkse, Marokkaanse en Kaap-Verdiaunse' Jongeren. GGD Rotterdam e.o., afdeling Jeugdzorg. 1992.

10. Uniken Venema H. P. Toen ik hier kwam was ik kerngezond. De gezondheid van Turken in Nederland. Bohn, Scheltema and Holkema, Rotterdam. 1989.

11. De Leefsituatie van Turken en Marokkanen in Nederland 1984. Deel 1: Eerste uitkomsten. CBS, Staatsuitgeverij Den Haag, 1986.

12. De Leefsituatie van Turken en Maroktanen in Nederkund 1984. Deel 2: Kerncijfers. CBS, Staatsuitgeverij Den Haag, 1986.
13. Gorissen W. H. M, Ticheler P. C. M, van Kessel R. P. $M$ and Souverein C. R. Gezondheidspeiling Utrecht. Resultaten van de gezondheidspeiling Utrecht 1986 1987. GG and GD, Utrecht, 1988.

14. Lamers L. M. and Reelick N. F. De Omnibusenquete 1991 onder Marokkanen. GGD Rotterdam e.o., afdeling Epideniologie 2, 1992.

15. Uniken Venema H. P., Klaus J. and Reelick N. F. De gezondheid van Surinamers. Epidemiol. Bull. 2, 11, 1991.

16. Kocken P.. Mackenbach J. P., van Oers J. A. M. and Uniken Venema H. P. Sterfte, ervaren gezondheid en gerapporteerd voorzieningengebruik van Rotterdamse Surinamers. Tijdschrift Soc. Gezondheidszong 725, 1994.

17. Geuns H. A. TBC en de volksgezondheid. Gezondheidszorg Turkse en Marokkaanse migranten. Boerhave commissic roor postacademisch onderwijs in de geneeskinde 115, 1982.

18. Gründemann R. W. M. Migranten, Gezondheid en Contactell met de Nederlandse Gezondheidszorg. NIPG/ TNO. Leiden, 1985.

19. van Knapen F., Verdonk A. R. and Franchimont J. H. Echinokose in Nederland. Nederlands Tijdschrift voor Geneeskinde 126 (24), 1982.

20. Avezaat J. J. M. and Lutjenhuis J. Th. Ulcus pepticum bij allochtone Nederlanders. Huisarts en Wetenschap 29, 218.1986

21. van de Laar M. J. W., Sleutjes M. P. M, Postema C. A. and van de Water H. P. A. Seksueel overdraagbare aandoeningen bij allochtone bevolkingsgroepen; een oriënterend onderzoek. Nederlands Tijdschrift voor Geneeskinde 135, 1542, 1991

22. van Wieringen J., Leentvaar-Kuypers A., Brouwer H., Slegt A. and van Kessel Al. H. Morbiditeitspatroon en Huisartsgeneeskundig Handelen Bij Etnische Groeperingen. Instituut voor Huisartsgeneeskunde en GG and GD Amsterdam. 1986.

23. Uniken Venema H. P. and Wierdsma A. I. Opnames van migranten in psychiatrische ziekenhuizen. Tijdschrift coor sociale Gezondheids=org 17, 37, 1992.

24. Cooper R. Race, disease and health. In Health, Race and Ethnicity (Edited by Rathwell Th. and Phillips D.). Croom Helm. Kent, 1986

25. Cooper R. A case study in the use of race and ethnicity in Public Health surveillance. Public Health Reports 109, 46. 1994.

26. Polednak A. P. Racial and Et/mic Differences in Disease. Oxford University Press. Oxford, 1989.

27. Murphy H. B. M. Migration. culture and mental health. Psichol. Med. 7, 677. 1977.

28. Kasl S. V. and Berkman L. Health consequences of the experience of migration. A. Rer. Public Hith 4, 69 , 1983.

29. Mackenbach J. P. Ongezonde verschillen. Over Sociale Stratificatic en Gezondheid in Nederland. Van Gorcumm, Assen, 1994.

30. Meulmeester J. F. Voedingsonderzoek bij Turkse en Marokkaanse kinderen in Nederland: voeding en voedingstoestand van achtjarige Turkse, Marokkaanse en Nederlandse schoolkinderen in "s-Gravenhage en Rotterdam. Proefschrift Amsterdam (UvA). 1988.

31. Hulshof P. J. M. Voeselconsumptie van in Nederland wonende volwassen Turken. Vakgroep Humane Voeding. Landbouwuniversiteit Wageningen, 1993.

32. in het Veld R. and van Steenbergen J. E. Kleurrijk Utrecht nader bekeken. Nadere analyse van de gezondheidssituatie van allochtonen in de stad Utrecht, op basis van de gezondheidspeiling. 1986, 87.

33. Middelkoop B. J. C. Cardiovasculaire risicofactoren en ethnische achtergrond: een onderzoek binnen het Rotterdams Huisartsen Project. Oral presentation WEON. 1994.

34. Swinkels H. GezondheidsenquÊtes: Rook-en drinkgedratg van Turkse inwoners van Nederland, 1989/1990. 
Maandbericht gezondheidsstatistiek. Jaargang 11 9, 5, 1992.

35. Augustijn H., de Graaf E. M. G. and van Stiphout W. A. H.J. Leefstijl en een positieve familie-anamnese voor hart-en vaatziekten. Een subanalyse naar de realiteit met ethnische herkomst. GGD Streekgewest Westelijk Noord Brabant (niet gepubliceerd verslag), 1993.

36. van Wersch S. F. M. and Uniken Venema H. P Gezondheid van Marokkaanse vrouwen. Gezondheidsbeleving, ziektegedrag en sociale netwerken van Marokkaanse en Nederlandse vrouwen in Rotterdam GGD Rotterdam e.o., afdeling Epidemiologie and Beleid 3, 1992.
37. Spruit J. Health care for laborer immigrants: perceptions of problems. In Migration and Health (Edited by Colledge M., van Geurs H. and Svensson P. G.). WHO, Copenhagen, 1986.

38. Kleinman A. Depression, Somatization and the new cross-cultural psychiatry. Soc. Sci. Med. 11, 3, 1977.

39. Kleinman A. Patients and Healers in the Context of Culture. University of California Press, Berkeley, 1980.

40. Nijs H. G. T., Kreuger F. A. F. and van Poel M. B. P. Bevolkingsonderzoek baarmoederhalskanker in Rotterdam e.o. Eerste ronde "nieuwe stijl" 1989-1991. GGD Rotterdam e.o., afdeling Epidemiologie and Beleid 93/12, 1993. 